\title{
Influence of Intracanal Post on Apical Periodontitis Identified by Cone-Beam Computed Tomography
}

\author{
Carlos ESTRELA ${ }^{1}$ \\ Mike Reis BUENO ${ }^{2}$ \\ Olavo César Lyra PORTO ${ }^{1}$ \\ Cleomar Donizeth RODRIGUES ${ }^{1}$ \\ Jesus Djalma PÉCORA ${ }^{3}$ \\ ${ }^{1}$ Dental School, Federal University of Goiás, Goiânia, GO, Brazil \\ ${ }^{2}$ Dental School, University of Cuiabá, Cuiabá, MT, Brazil \\ ${ }^{3}$ Dental School, University of São Paulo, Ribeirão Preto, SP, Brazil
}

\begin{abstract}
The determination of the success of endodontic treatment has been often discussed based on outcome obtained by periapical radiography. The aim of this study was to verify the influence of intracanal post on apical periodontitis detected by cone-beam computed tomography (CBCT). A consecutive sample of 1020 images (periapical radiographs and CBCT scans) taken from 619 patients (245 men; mean age, 50.1 years) between February 2008 and September 2009 were used in this study. Presence and intracanal post length (short, medium and long) were associated with apical periodontitis (AP). Chi-square test was used for statistical analyses. Significance level was set at $\mathrm{p}<0.01$. The kappa value was used to assess examiner variability. From a total of 591 intracanal posts, AP was observed in $15.06 \%, 18.78 \%$ and $7.95 \%$ using periapical radiographs, into the different lengths, short, medium and long, respectively ( $\mathrm{p}=0.466$ ). Considering the same posts length it was verified AP in $24.20 \%, 26.40 \%$ and $11.84 \%$ observed by CBCT scans, respectively ( $\mathrm{p}=0.154$ ). From a total of 1,020 teeth used in this study, AP was detected in 397 (38.92\%) by periapical radiography and in 614 (60.19\%) by CBCT scans $(p<0.001)$. The distribution of intracanal posts in different dental groups showed higher prevalence in maxillary anterior teeth (54.79\%). Intracanal posts lengths did not influenced AP. AP was detected more frequently when CBCT method was used.
\end{abstract}

Key Words: apical periodontitis, cone beam computed tomography, root canal obturation, intracanal post, endodontic success.

\section{INTRODUCTION}

The success of endodontic treatment is related to the elimination of etiologic factors of periapical problems from the root canal system allied to a hermetic sealing by filling material with excellent physical and biological properties (1). The knowledge of all implications involved with endodontic treatment, clinical factors or apical periodontitis (AP) is essential to choose between the preventive actions or the therapeutic protocol (2). $\mathrm{AP}$ is a consequence of root canal system infection, which can involve progressive stages of inflammation and changes of periapical bone structure, resulting in resorption identified as radiolucencies in radiographs (3), which corresponds to a two-dimensional aspect of a three-dimensional structure (4). Periapical radiography is habitually used for diagnosis, treatment planning, and follow up endodontic treatment, and its benefits and limitations should be well-known (3-5).

The prevalence and risk factors of AP in 1,372 periapical radiographs of endodontically treated teeth in a selected population of Brazilian adults was recently studied (2). The quality of root filling, status of coronal restoration and presence of posts associated with AP were analyzed. The findings of the present investigation showed that the prevalence of AP was low when associated with high technical quality of root canal treatment. Poor coronal restoration increased the risk of AP even when endodontic treatment was adequate. The presence of intracanal posts had no influence on the risk of AP based on two-dimensional aspects offered by periapical radiographs. Holland et al. (1) reported that

Correspondence: Prof. Dr. Carlos Estrela, Centro de Ensino e Pesquisa Odontológica do Brasil (CEPOBRAS), Avenida C-198, quadra 487, Lote 9, Jardim América, 74270-040 Goiânia, GO, Brasil. Tel/Fax: +55-62-3945-7476. e-mail: estrela3@terra.com.br 
the marginal coronal leakage after post space preparation is an expressive problem for endodontic treatment and all efforts should be directed to its elimination. Specific studies addressing this issue are very important to improve the understanding of the problem and possibilities of resolution.

The functional restoration of the tooth may involve the necessity of root canal treatment associated with or without intracanal post, with function of reestablishment the dental structure lost. Kvist et al. (6) determined the relation between technical quality of root filling seal in teeth with posts and radiographic status of the periapical tissues. Periapical radiolucencies were judged to be present in $16 \%$ of roots with posts and in $13 \%$ of roots without posts. Roots with posts in which the remaining root filling was shorter than $3 \mathrm{~mm}$ showed a statistically significant higher frequency of periapical radiolucencies. It was found that an improper seal was more unfavorable in roots with posts. The findings of this study indicate that the placement of a post will not per se decrease the probability of periapical healing. It also suggests that the remaining root filling must not be shorter than $3 \mathrm{~mm}$.

On the other hand, in view of recent technological advances some concepts of endodontic would be reconsidered, specially after new imaging modalities had been added to dental radiology as viable diagnostic tools, namely digital radiography, densitometry methods, cone-beam computed tomography (CBCT), magnetic resonance imaging, ultrasound, nuclear techniques $(5,7,8)$. Some diagnostic tools, like CBCT scan providing detailed high-resolution images of oral structures and allowing early detection of bone lesions with view in three dimensions. CBCT has been used for several clinical and investigational purposes in endodontics $(5,8-11)$.

Estrela et al. (5) evaluated the accuracy of CBCT images, periapical and panoramic radiographs for AP identification. The prevalence of AP in endodontically treated teeth by using panoramic and periapical radiographs and CBCT images was $17.6 \%, 35.3 \%$, and $63.3 \%$, respectively. CBCT was an accurate diagnostic method to detect AP. Wu et al. (12) discussed the limitations of previously published systematic reviews evaluating the outcome of root canal treatment. Periapical radiography has been used to assess the outcome of root canal treatment with the absence of a periapical radiolucency being considered a confirmation of a healthy periapical region. These authors considered that periapical radiography was the only imaging method available to diagnose posttreatment AP until recently. With the development of CBCT techniques, a better understanding of the outcome of root canal treatment becomes possible. The success of root canal treatment should be re-evaluated in longterm studies using $\mathrm{CBCT}$ and more rigorous criteria.

Considering all aspects regarding the limitations of periapical radiographs $(5,12)$, which are often used to distinguish a healthy periodontal condition from AP, this study evaluated evaluated the influence of intracanal post on AP in endodontically treated teeth detected by CBCT scans.

\section{MATERIAL AND METHODS}

\section{Patients}

A consecutive sample of 1,020 images (periapical radiographs and CBCT scans) firstly taken from 619 patients ( 245 men; mean age, 50.1 years) between February 2008 and September 2009 were selected from the database of the Radiological Center of Orofacial Images (CROIF, Cuiabá, MT, Brazil). All patients had 1 or more teeth with history of endodontic treatment. Some of the teeth presented AP identified radiographically. The sample involved in the study were maxillary anterior teeth $(\mathrm{n}=251)$, mandibular anterior teeth $(\mathrm{n}=24)$, maxillary premolars $(\mathrm{n}=228)$, mandibular premolars $(\mathrm{n}=196)$, maxillary molars $(\mathrm{n}=198)$, mandibular molars $(n=123)$. From 1,020 endodontically treated teeth examined in this study, 539 teeth presented 591 roots with intracanal posts.

\section{Imaging Methods}

The periapical radiographs were taken with a Spectro $\times 70$ electronic $x$-ray unit (Dabi Atlante, Ribeirão Preto, SP, Brazil) by using a $0.8 \mathrm{~mm}$ X $0.8 \mathrm{~mm}$ tube focal spot, Kodak Insight film-E (Eastman Kodak Co, Rochester, NY, USA) and a parallel radiography technique. All films were processed in an automatic processor and developed by using standardized methods. CBCT images were obtained with an I-CAT Cone Beam 3D imaging system (Imaging Sciences International, Hatfield, PA, USA), $0.20 \mathrm{~mm}-0.20 \mathrm{~mm}-0.20 \mathrm{~mm}$ voxel size, 14 bits. Images were examined by using the software (Xoran version 3.1.62; Xoran Technologies, Ann Arbor, MI, USA) in a PC workstation running Microsoft Windows 
XP professional SP-2 (Microsoft Corp, Redmond, WA, USA). Three calibrated blinded examiners evaluated all digital images verifying the presence of AP by periapical radiography and $\mathrm{CBCT}$ related to with intracanal post length in relation of root (short - equal or smaller than $1 / 3$ of root; medium - smaller than $2 / 3$ of root; long equal or greater than $2 / 3$ of root). These posts length were based on stand of previous study (13). Chi-square test was used for statistical analyses. Significance level was set at $p<0.01$. The kappa value was used to assess examiner variability.

\section{RESULTS}

From a total of 591 intracanal posts it was observed AP in $15.06 \%, 18.78 \%$ and $7.95 \%$ using periapical radiographs, into different lengths, short, medium and long, respectively $(\mathrm{p}=0.466)$. Considering the same posts length it was verified AP in $24.20 \%, 26.40 \%$ and $11.84 \%$ observed by CBCT scans, respectively ( $\mathrm{p}=0.154)$. In both imaging methods the posts length did not influence on prevalence of AP. Although, AP was identified in more number of cases by using CBCT scans. The distribution of intracanal post in different dental groups showed higher prevalence in maxillary anterior teeth $(54.79 \%)$ when compared with others groups (Table 1). From a total of 1,020 teeth used in this study, AP was detected in 397 (38.92\%) by periapical radiographs and in 614 $(60.19 \%)$ by CBCT scans $(\mathrm{p}<0.001)$ (Fig. 1$)$.

The Kappa values showed superior than 0.81 .

\section{DISCUSSION}

Table 1. Influence of intracanal post length on apical periodontitis detected by periapical radiography and CBCT.

\begin{tabular}{|c|c|c|c|c|c|c|}
\hline \multirow{2}{*}{$\begin{array}{l}\text { Imaging } \\
\text { exams }\end{array}$} & \multirow{2}{*}{$\begin{array}{c}\text { Apical } \\
\text { periodontitis }\end{array}$} & \multicolumn{3}{|c|}{ Intraradicular post lenght $(\mathrm{n}=591)$} & \multirow[t]{2}{*}{ Total } & \multirow[t]{2}{*}{ p value* } \\
\hline & & Short & Medium & Long & & \\
\hline \multirow{2}{*}{$\begin{array}{l}\text { Periapical } \\
\text { radiograph }\end{array}$} & Presence & $89(15.06 \%)$ & $111(18.78 \%)$ & $47(7.95 \%)$ & $247(41.79 \%)$ & \multirow{2}{*}{$\mathrm{p}=0.466$} \\
\hline & Absence & $126(21.32 \%)$ & $140(23.69 \%)$ & $78(13.20 \%)$ & $344(58.21 \%)$ & \\
\hline \multirow[t]{2}{*}{ CBCT } & Presence & $143(24.20 \%)$ & $156(26.40 \%)$ & $70(11.84 \%)$ & $369(62.44 \%)$ & \multirow{2}{*}{$\mathrm{p}=0.154$} \\
\hline & Absence & $72(12.18 \%)$ & $95(16.07 \%)$ & $55(9.31 \%)$ & $222(37.565)$ & \\
\hline
\end{tabular}

*From a total of 1,020 teeth analyzed in this study, AP was detected in 397 (38.92\%) by periapical radiography and in 614 (60.19\%) by CBCT scans. 

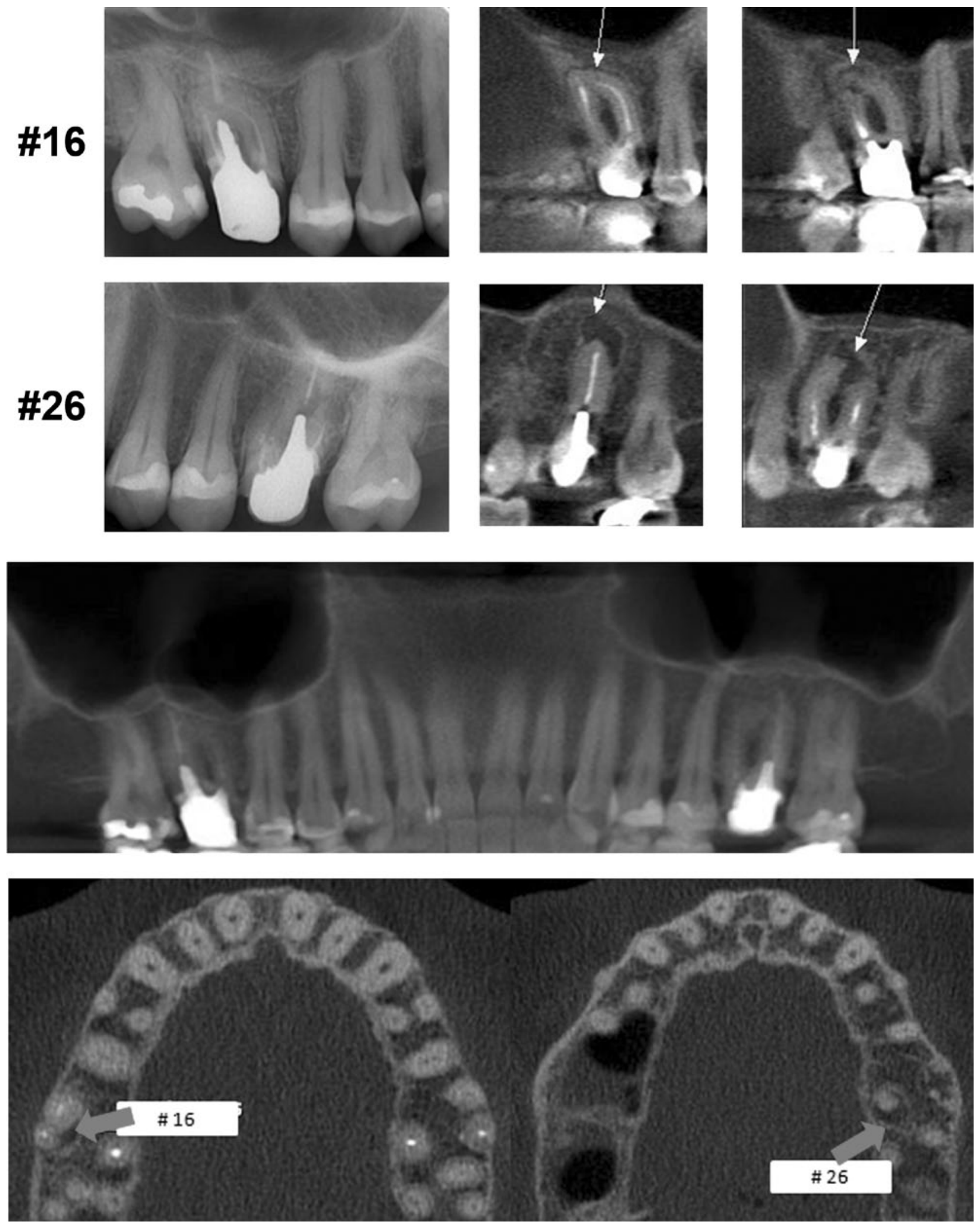

Figure 1. Apical periodontitis is identified in maxillary molars with intracanal posts using CBCT scans and occulted by periapical radiography. 
higher than in the others groups (premolars and molars) (Table 1).

With the advent of new diagnosis methods that allow a three-dimensional plane, images of high diagnostic quality may be obtained $(7-12,14,15)$. Estrela et al. (5) reported that the use of conventional radiographic images for detection of AP should be done with care because of the high possibility of false-negative diagnosis. A great advantage of using CBCT in endodontics refers to its usefulness in aiding in the identification of periapical lesions and in a differential diagnosis with a noninvasive technique with high accuracy. AP prevalence in endodontically treated teeth showed a considerable discrepancy (panoramic radiographs - 17.6\%; periapical radiographs - 35.3\%; CBCT scans - 63.3\%). This fact was also observed in the present study. Wu et al. (12) reported that several factors could have contributed to the overestimation of successful outcomes after root canal treatment. It may be emphasized the high percentage of cases that are confirmed as healthy by periapical radiography presenting AP; in CBCT images and histology exam; in teeth, where reduced size of the existing radiolucency is diagnosed by periapical radiography and considered to represent periapical healing, enlargement of the lesion may frequently be confirmed by CBCT. Paula-Silva et al. (15) observed evidences of the superiority of CBCT scans for the detection of periapical disease compared with periapical radiography, with unfavorable outcomes after one-visit therapy compared to 2-visit therapy.

The results of this study on higher precision of CBCT scans into identifing AP is according to previous studies $(5,10,12,14,15)$. The relation of intracanal post lengths did not influence the prevalence of AP. This information is also in agreement with earlier study (2) that, based on 2-dimensional aspects offered by periapical radiographs, also did not find relation with intracanal posts and AP.

Intracanal post per se will not decrease the probability of periapical healing (6).

AP was detected in all intracanal post lengths, regardless of imaging method, which indicated that the post length might not be associated with AP when the root canal was not perfectly cleaned, shaped, and 3-dimensionally filled in with a good coronal restoration. These aspects were discussed recently (14) when it was determined the influence of length of root canal obturation ( $2 \mathrm{~mm}, 1 \mathrm{~mm}$ short or beyond apex, and at the apex) on the presence of AP. AP also was detected at all lengths of root canal obturation. The rates of endodontic treatment success are influenced by the quality of root canal preparation and coronal sealing. The complex root canal system anatomy and the presence of endodontic biofilm may contribute to higher rates of endodontic failures (16-19). Therefore, the quality of endodontic practice, infection control, and endodontic treatment performed by a clinical dentist or endodontic specialist were not evaluated. In function of the design of the present study, some aspects might not be analyzed, and possibility might affect the results, like mentioned in others studies $(5,10,14)$ : the impossibility to accurately determine pulp condition before treatment (vital pulp, necrotic pulp, AP, primary or secondary infection, periapical abscess without or with sinus tract, clinical symptoms such as presence or absence of pain, open or closed cavity). The quality of post space preparation, the lapse of time to definitively cementation of the post and the remaining root canal may implicate on bacterial leakage and conduce to unfavorable prognosis. Holland et al. (1) evaluated the coronal leakage after post space preparation in dogs' teeth. It was shown that a sealer quality with good physical and biological properties and the use of a plug covering the remaining filling can contribute to avoid or decrease microorganisms leakage.

The prevalence of intracanal post was major in maxillary anterior teeth $(54.79 \%)$ than in others the groups (Table 1). Considering a total of 1,020 teeth evaluated, AP was detected in 397 (38.92\%) by periapical radiographs and in 614 (60.19\%) by CBCT scans. Lopes et al. (13) evaluated through periapical radiographs the post length and quality of the root canal obturation of teeth with cast dowel and core. In $80.4 \%$ of teeth analyzed, the cast and core had short posts. In 50.4\% root with cast dowel and core it was found in teeth with improper root canal obturation.

Higher prevalence of endodontically treated teeth $(21.4 \%)$ has been observed in a Brazilian adult population compared to the prevalence reported in epidemiological studies conducted in other countries. Maxillary premolars and molars were endodontically treated teeth most frequent found, whereas mandibular incisors showed the lowest prevalence (20).

This cross-sectional study was based on previous studies $(2,5,10,14,20)$, that analyzed images from a database, with the purpose of to establishing the influence of intracanal post on AP using CBCT scans. It can be observed higher number of cases with AP by using 
CBCT method (Table 2). This aspect showed the necessity to review epidemiologic studies that considered the quality of periapical aspects evaluated by panoramic or periapical radiographs $(5,10,14)$.

Considering the limitations of this essay, it may be concluded that the intracanal posts lengths did not influenced AP. When CBCT method was used, the AP was detected more frequently. Maxillary anterior teeth present higher frequency $(54.79 \%)$ of intracanal post.

\section{RESUMO}

O objetivo deste estudo foi determinar a influência de retentores intraradiculares na periodontite apical (PA), detectados por radiografia periapical (RP) e tomografia computadorizada de feixe cônico (TCFC). Um total de 1.020 imagens, tomadas de 619 pacientes ( 245 homens, idade média de 50,1 anos), entre Fevereiro de 2008 e Setembro de 2009, foram avaliadas. A presença e o comprimento de retentores intraradiculares (curto, médio e longo) foram associados com a PA. Os dados foram estatisticamente avaliados empregando-se os testes Qui-quadrado e o Kappa. Três observadores avaliaram todas as imagens, considerando-se a presença de retentor intraradicular, seu comprimento e a PA. De um total de 1.020 dentes analisados no estudo, a PA foi detectada em 397 (38,92\%) usando RP e em 614 (60,19\%) usando TCFC $(p<0,001)$. Em 591 retentores intraradiculares, nos diferentes comprimentos (curto, médio, longo) foram observadas PA usando RP em $15,06 \% ; 18,78 \%$ e $7,95 \%$, respectivamente $(p=0,466)$. Considerando os mesmos comprimentos de retentores foram observados PA em $24,20 \% ; 26,40 \%$ e $11,84 \%$ por meio de TCFC, respectivamente $(\mathrm{p}=0,154)$. A distribuição de retentores nos diferentes grupos dentários mostrou elevada prevalência em dentes anteriores superiores $(54,79 \%)$. Os retentores intraradiculares não influenciaram a PA e as TCFC detectaram mais freqüentemente a periodontite apical.

\section{ACKNOWLEDGMENTS}

This study was supported in part by grants from the Nacional Council for Scientific and Technological Development (CNPq grants $302875 / 2008-5$ to C.E.). We thank Prof. Hélio Pereira Lopes for all sugestions to this study.

\section{REFERENCES}

1. Holland R, Manne LN, Souza V, Murata SS, Dezan-JR E. Periapical tissue healing after post space preparation with or without use of a protection plug and root canal exposure to the oral environment. Study in dogs. Braz Dent J 2007;18:281-288.

2. Estrela C, Leles CR, Hollanda ACB, Moura MS, Pécora JD. Prevalence and risk factors of apical periodontitis in endodontically treated teeth in a selected population of Brazilian adults. Braz Dent J 2008;19:34-39.
3. Nair PNR, Sjögren U, Figdor D, Sundqvist G. Persistent periapical radiolucencies of root-filled human teeth, failed endodontic treatments, and periapical scars. Oral Surg Oral Med Oral Pathol Oral Radiol Endod 1999;87:617-627.

4. Bender IB. Factors influencing the radiographic appearance of bone lesions. J Endod 1982;8:161-170.

5. Estrela C, Bueno MR, Leles CR, Azevedo B, Azevedo JR. Accuracy of cone beam computed tomography and panoramic and periapical radiography for detection of apical periodontitis. J Endod 2008;34:273-279.

6. Kvist T, Rydin E, Reit C. The relative frequency of periapical lesions in teeth with root canal-retained posts. J Endod 1989;15:578580.

7. Huumonen S, Ørstavik D. Radiological aspects of apical periodontitis. Endod Topic 2002;1:3-25.

8. Nair MK, Nair UP. Digital and advanced imaging in endodontics: a review. J Endod 2007;33:1-6.

9. Arai Y, Tammisalo E, Iwai K, Hashimoto K, Shinoda K. Development of a compact computed tomographic apparatus for dental use. Dent Maxillofac Radiol 1999;28:245-248.

10. Estrela C, Bueno MR, Azevedo B, Azevedo JR, Pécora JD. A new periapical index based on cone beam computed tomography. J Endod 2008;34:1325-1331.

11. Estrela C, Bueno MR, Alencar AHG, Mattar R, Azevedo B, Valladares-Neto J, Estrela CRA. Method for evaluation of inflammatory root resorption based on cone beam computed tomography. J Endod 2009;35:1471-1477.

12. Wu M-K, Shemesh H, Wesselink PR. Limitations of previously published systematic reviews evaluating the outcome of endodontic treatment. Int Endod J 2009;42:656-666.

13. Lopes HP, Estrela C, Rocha NSM, Costa-Filho A, Siqueira-JR JF. Intracanal post: radiographic analysis of post lenght and quality of root canal obturation. Rev Bras Odontol 1997;54:277-280.

14. Moura MS, Guedes AO, Alencar ANG, Azevedo BC, Estrela C. Influence of length of root canal obturation on apical periodontitis detected by periapical radiography and cone beam computed tomography. J Endod 2009;35:805-809.

15. Paula-Silva FWG, Hassan B, Silva LAB, Leonardo MR, Wu MK. Outcome of root canal treatment in dogs determined by periapical radiography and cone-beam computed tomography scans. J Endod 2009;35:723-726.

16. Nair PNR, Henry S, Cano V, Vera J. Microbial status of apical root canal system of human mandibular first molars with primary apical periodontitis after one-visit-endodontic treatment. Oral Surg Oral Med Oral Pathol Oral Radiol Endod 2005;99:231-252.

17. Estrela C, Sydney GB, Figueiredo JAP, Estrela CRA. Antibacterial efficacy of intracanal medicaments on bacterial biofilm: a critical review. J Appl Oral Sci 2009;17:1-7.

18. Estrela C, Estrela CRA, Decurcio DA, Hollanda ACB, Silva JA. Antimicrobial efficacy of ozonated water, gaseous ozone, sodium hypochlorite and chlorhexidine in infected human root canals. Int Endod J 2007;40:85-93.

19. Estrela C, Holland R, Bernabé PFE, Souza V, Estrela CRA. Antimicrobial potential of medicaments used in healing process in dog's teeth with apical periodontitis. Braz Dent J 2004;15:12-16.

20. Hollanda ACB, Alencar AHG, Estrela CRA, Bueno MR, Estrela C. Prevalence of endodontically treated teeth in a Brazilian adult population. Braz Dent J 2008;19:313-317.

Accepted November 19, 2009 